\title{
Antibacterial Activity of Leptadenia Hastata Leaves Extracts against Some Gastro-Intestinal Isolates
}

\author{
Ibrahim U Imam ${ }^{1}$, Muhammad S Abdallah ${ }^{2}$ and Muhammad Ali*3 \\ ${ }^{1}$ Department of Vector and Parasitology, Nigerian Institute for Trypanosomiasis and Onchocerciasis Research Kaduna, Nigeria \\ ${ }^{2}$ Desert Research Monitoring and Control Centre, Yobe State University Damaturu, Nigeria \\ ${ }^{3}$ Department of Microbiology, Federal University Gusau, Nigeria
}

*Corresponding author: Muhammad Ali, Department of Microbiology, Federal

University Gusau, Nigeria.

Received Date: April 13, 2019

Published Date: April 22, 2019

\begin{abstract}
At present, drug discovery research is mainly focused on plant resources and their compounds. The study was conducted to determine the phytochemical composition and antibacterial property of Leptadenia hastata leaf extracts against some gastro-intestinal isolates. Clinical isolates of Escherichia coli, Proteus mirabilis, Staphylococcus aureus, Salmonella typhi, Klebsiella pneumoniae and Shigella dysenteriae isolated from patients diagnosed with gastro-intestinal disorder were obtained from Microbiology laboratory of Murtala Mohammed Specialists Hospital Kano. Aqueous and ethanol extracts of Leptadenia hastata were prepared separately and subjected for phytochemical screening and antibacterial activity. The antibacterial activity of the extracts was determined using the agar well diffusion. The result indicated the presence of alkaloid, saponin, phenol, flavonoids, glycoside, tannin, steroid and terpenoid in both aqueous and ethanol extracts. The results of antibacterial activity of Leptadenia hastata leaf extracts indicated that extracts possessed antibacterial activity with variable degree of sensitivity against isolates with ethanol extract having higher activity $(12.56 \mathrm{~mm})$ than aqueous extract which has an average zone of inhibition of $11.22 \mathrm{~mm}$. statistical analysis of the results showed that $\mathrm{S}$. aureus is the most sensitive isolate. However, there are no statistical significant differences on the sensitivity of the isolates at $\mathrm{p}<0.05$. It is concluded that the extracts of $\mathrm{L}$. hastata possessed antibacterial agents.
\end{abstract}

Keywords: Antibacterial activity; Bacteria; Leptadenia hastata; Gastro-intestinal disorder

\section{Introduction}

Natural products have been used over the years as curative agents against many infections and have been exploited in the traditional medicine with their curative potentials well documented [1]. Natural products are defined as natural sources-derived substances having biological activities. These natural products have long been implemented as alternative health care treatment and in the discovery of modern drugs [2]. A major focus of natural product in chemistry has been toward drug design and discovery. However, obtaining scientific proof for the biological activity of natural plants is still challenging [3]. At present, drug discovery research is mainly focused on natural plant resources and their compounds. Most of the currently available therapeutically active drugs are discovered based on the knowledge available from various traditional practices for disease treatments [4].

Leptadenia hastata (Pers.) Decne is a perennial plant of the family of Asclepediaceae, the plant is edible non-domesticated vegetable and it is collected in wild throughout Africa. It is one of the important medicinal herbs used in Africa by the traditional healers for treatment of disease and ailment and for food by the local people in terms of hunger due to its high content of valuable nutrients rich in various types of amino acids, fatty acids, terpenes, carotenes, luteines and poly-oxy pregnane [5]. The plant is commonly used in the Northern Nigeria as spices and sauces [6]. Local healers also use the plant for hypertension, catarrh and skin diseases [7]. In certain areas of West Africa, breeders claimed the antifertility effect of their animals after consumption of the leaf and stems of Leptadenia hastata [1]. The main phytochemical constituents of the plant are carbohydrates, steroids, glycosides, flavonoids, tannins, and phenolic compounds [8]. A phytochemical screening conducted by Bello, et al. [9] on Leptadenia hastata leaves extract indicate the presence of phenolic glycosides, tannins, flavonoids, proanthocyanidins, alkaloids and saponins. 
Aliero and Wara [10] studied the antibacterial activity Leptadenia hastata leaves extract against Bacillus sp, Staphylococcus aureus, Escherichia coli, Salmonella paratyphi and Pseudomonas aeruginosa strains. They observed clear zones of inhibition after the incubation period. In a study conducted to evaluate the in vitro antibacterial potentials of Leptadenia hastata extracts, the result showed that extracts exhibited antibacterial activities against Gram-positive (Staphylococcus aureus ATCC 29213 and clinical strain of Staphylococcus aureus), and Gram-negative (Escherichia coli ATCC 25922, Pseudomonas aeruginosa ATCC 27853, and clinical strains Salmonella typhi, Klebsiella pneumoniae) bacteria [11]. The activity of the plant may be as a result of the presence of; alkaloids, saponins, phenolic glycosides, tannins, flavonoids, proanthocyanidins and triterpenes [12]. In many African countries, the plant is used as medicine due to its nutritive and therapeutic properties for the treatment of wounds and stomach upset conditions in children [10]. In view of this, the study was conducted to determine the phytochemical composition and antibacterial property of Leptadenia hastata leaf extracts against some gastrointestinal isolates.

\section{Materials and Methods}

\section{Ethical approval}

Ethical clearance (MOH/off/797/T.I/49) for the study was obtained from Kano State Ministry of Health through Health Service Management Board Kano with the consent of Murtala Muhammad Specialist Hospital Kano ethical committee

\section{Study Area}

Clinical isolates of Escherichia coli, Proteus mirabilis, Staphylococcus aureus, Salmonella typhi, Klebsiella pneumoniae and Shigella dysenteriae isolated from patients diagnosed with gastro-intestinal disorder were obtained from Microbiology laboratory of Murtala Mohammed Specialists Hospital Kano. Characterization of the isolates and determination of antimicrobial activity of the extracts against the isolates was conducted in the Departments of Microbiology of Kano University of Science and Technology Wudil. Phytochemical screening of the extract was done at Biochemistry laboratory of Bayero University, Kano.

\section{Characterization of the isolates}

The isolates were characterized by conventional microbiological methods: Gram staining, Biochemical test (indole, methyl-red, voges proskauer and citrate utilization), motility and lactose fermentation test. Gram staining was done according to the methods described by Cheesbrough [13]. Biochemical tests were done according to the method described by Holt et al. [14]. Lactose fermentation test was done by inoculating the isolates onto the surface of MacConkey agar and incubated at $370 \mathrm{C}$ for 24 hours [14].

\section{Identification of plant materials}

Letadenia hastata leaves were used in this study. The plant material was obtained at about 7:30 am on 23rd October, 2017 at Mariri village in Kumbotso Local Government Area of Kano State.
Identification and authentication of the plant material was done at Herbarium in the Department of Plant Science, Bayero University Kano with the following voucher number BUKHAN 248 and voucher specimen were deposited there for reference.

\section{Preparation of extracts}

Aqueous and ethanol extracts of Leptadenia hastata were prepared separately. The fresh leaves were washed and air dried for two weeks. After drying, the leaves were grounded to fine powder using sterile pestle and mortar under laboratory condition. Fifty grams $(50 \mathrm{~g})$ powder of the plant material was soaked in $500 \mathrm{ml}$ each of distilled water and ethanol respectively. The flasks were kept at room temperature for 3 days with intermittent shaking after which filtration was done using Whatman filter paper. The ethanol extracts was evaporated at $60^{\circ} \mathrm{C}$ using rotary evaporator while the aqueous extract was evaporated at $70^{\circ} \mathrm{C}$ in water bath until dried extract samples were obtained. All the dried extract samples were dissolved in 30\% DMSO separately to the final concentration of 200 $\mathrm{mg} / \mathrm{mL}$ as a stock concentration. Various concentrations of 100, 75, 50 and $25 \mathrm{mg} / \mathrm{mL}$ were made from the stock concentration. The extract solutions were stored at $4^{\circ} \mathrm{C}$ before use [15].

\section{Qualitative phytochemical screening}

The screening of the phytochemical constituents of the plant materials for various phytochemical constituents such as terpenoids, flavonoids, alkaloids, reducing sugars, steroid, glycoside, phenol, Anthraquinones, saponin and tannin was conducted using standard methods as described by Sofowora [16] and Trease and Evans [17].

\section{Antibacterial activity of the extracts}

The antibacterial activity of the extracts was determined using the agar well diffusion [18]. The prepared bacterial suspension equivalent to 0.5 McFarland Standard (1.5 x $106 \mathrm{CFU}$ ) was inoculated onto sterile surface of Mueller- Hinton agar medium (MHA) in a Petri-dish. A cork borer of $6 \mathrm{~mm}$ diameter size was utilized to produce 5 holes at equidistance on the medium. The holes were supplied with approximately $0.1 \mathrm{~mL}$ of the prepared extracts at a various concentration of $25,50,75$ and $100 \mathrm{mg} / \mathrm{mL}$ respectively. The plates were allowed to diffuse on the laboratory bench for 1 hour. The inoculated plates were incubated at $370 \mathrm{C}$ for 24 hours. Zones of inhibition produced by the extracts against the test isolates were observed and measured. The experiment was conducted in triplicate and the average values were recorded. Amoxicillin $50 \mathrm{mg} / \mathrm{mL}$ (Micro Lab limited) was used as positive control in the experiment.

\section{Evaluation of Minimum Inhibitory Concentration (MIC)}

Broth dilution technique was employed to determine the minimum inhibitory concentration MIC of the extracts. Double fold dilutions were prepared by adding $2 \mathrm{~mL}$ of $100 \mathrm{mg} / \mathrm{mL}$ of the extract into a test tube containing $2 \mathrm{~mL}$ of Nutrient broth, thus producing solution containing $50 \mathrm{mg} / \mathrm{mL}$ of the extract. The process continues serially up to test tube No. 5, hence producing the following concentrations; $50,25,12.5,6.25$ and $3.125 \mathrm{mg} / \mathrm{mL}$ respectively. Test tube Number 6 does not contain extracts and serve as negative 
control. Exactly $0.5 \mathrm{~mL}$ of $0.5 \mathrm{McF}$ arland equivalent standards of test organisms were introduced into the test tubes and incubated at $370 \mathrm{C}$ for 24 hours. After incubation the test tubes were observed for growth by checking for turbidity [18].

\section{Determination of Minimum Bactericidal Concentration (MBC)}

From each tube that did not show visible growth in the MIC, Briefly, $0.1 \mathrm{~mL}$ bacterial culture was pipette from MIC tubes which did not show any growth and sub cultured onto the surface of Mueller Hilton agar plates. The inoculated plates were incubated at $370 \mathrm{C}$ for the period of 24 hours. The MBC was recorded as the lowest concentration of extract without single colony of bacteria on Mueller Hilton agar plates [18].

\section{Statistical Analysis}

The data obtained on antibacterial activity of the extracts against the test isolates was analyzed using One-way analysis of variance (ANOVA). All the data were computed as means \pm standard deviation using statistical program SPSS 21.0 (Statistical Package for the Social Sciences). Probability value of 0.05 was set to determine significant differences level on the activity of the extracts against the tested isolates.

\section{Results}

\section{Phytochemical screening}

The phytochemical constituents of Leptadenia hastata leaf extract is presented in Table 1 . The result indicated the presence of alkaloid, saponin, phenol, flavonoids, glycoside, tannin, steroid and terpenoid in both aqueous and ethanol extracts (Table 1).

Table 1: Phytochemical constituents of Leptadenia hastata leaf extract.

\begin{tabular}{|c|c|c|c|c|}
\hline S/N & Phytochemicals & Test & $\begin{array}{c}\text { Aqueous } \\
\text { extract }\end{array}$ & $\begin{array}{c}\text { Ethanol } \\
\text { extract }\end{array}$ \\
\hline 1 & Alkaloid & Wagner's test & + & + \\
\hline 2 & Saponin & Foam test & + & + \\
\hline 3 & Phenol & $\begin{array}{c}\text { Ferric chloride } \\
\text { test }\end{array}$ & + & + \\
\hline 4 & Flavonoid & Lead acetate test & + & + \\
\hline 5 & Glycoside & Fehling test & + & + \\
\hline 6 & Tannin & Gelatin test & + & + \\
\hline 7 & Reducing sugar & Fehling test & - & - \\
\hline 8 & Anthraquinone & Benzene test & - & - \\
\hline 9 & Steroid & Acetic test & + & + \\
\hline 10 & Terpenoid & Salkowski test & + & + \\
\hline
\end{tabular}

Key: $+=$ Presence of phytochemical, - = Absence of phytochemical.

\section{Antibacterial activity of aqueous extract}

The antibacterial activity of aqueous extract of L. hastata leaf is presented in Table 2 below. The results showed that zones of inhibition recorded by the isolates depend on the type of bacterial isolates and concentration of the extracts. Highest zone of inhibition was demonstrated by S. aureus $(16.25 \mathrm{~mm})$ at $100 \mathrm{mg} / \mathrm{mL}$. The zone of inhibition of the control (Amoxicillin $50 \mathrm{mg} / \mathrm{mL}$ ) ranges from to $17.67-20.67 \mathrm{~mm}$ (Table 2).

Table 2: Antibacterial activity of $L$ hastata aqueous extract.

\begin{tabular}{|c|c|c|c|c|c|}
\hline \multirow{2}{*}{ Isolates } & \multicolumn{5}{|c|}{ Concentration $(\mathrm{mg} / \mathrm{mL}) /$ Zone of inhibition (mm) } \\
\hline & 25 & 50 & 75 & 100 & Control \\
\hline Klebsiella pneumoniae & $7.25 \pm 0.10 \mathrm{a}$ & $8.05 \pm 0.12 \mathrm{a}$ & $10.23 \pm 0.11 \mathrm{~b}$ & $12.87 \pm 0.23 \mathrm{c}$ & 17.67 \\
\hline Salmonella typhi & $8.34 \pm 0.17 \mathrm{a}$ & $10.33 \pm 0.13 b$ & $11.66 \pm 0.12 \mathrm{~b}$ & $14.12 \pm 0.16 \mathrm{c}$ & 19.34 \\
\hline Shigella sp & $8.40 \pm 0.17 \mathrm{a}$ & $10.95 \pm 0.10 \mathrm{a}$ & $13.32 \pm 0.19 \mathrm{~b}$ & $15.71 \pm 0.21 \mathrm{c}$ & 19.34 \\
\hline Staphylococcus aureus & $8.55 \pm 0.00 \mathrm{a}$ & $11.27 \pm 0.16 \mathrm{~b}$ & $13.69 \pm 0.13 \mathrm{bc}$ & $16.25 \pm 0.24 \mathrm{c}$ & 20.67 \\
\hline Escherichia coli & $8.67 \pm 0.30 \mathrm{a}$ & $10.29 \pm 0.17 \mathrm{a}$ & $13.34 \pm 0.13 \mathrm{~b}$ & $14.43 \pm 0.26 \mathrm{~b}$ & 18.34 \\
\hline Proteus mirabilis & $7.32 \pm 0.14 \mathrm{a}$ & $8.45 \pm 0.20 \mathrm{a}$ & $12.63 \pm 0.25 \mathrm{~b}$ & $13.30 \pm 0.14 \mathrm{~b}$ & 19.67 \\
\hline
\end{tabular}

Key: Values having different superscript on the same row are considered significantly different at $p<0.05$

\section{Antibacterial activity of ethanol extract}

The antibacterial activity of ethanol extract of L. hastata is presented in Table 3. The results showed that zones of inhibition recorded by the isolates depend on the type of bacterial isolates and concentration of the extracts. Highest zone of inhibition was demonstrated by S. aureus (17.41 mm) at $100 \mathrm{mg} / \mathrm{mL}$. The zone of inhibition of the control (Amoxicillin $50 \mathrm{mg} / \mathrm{mL}$ ) ranges from to $17.67-20.67 \mathrm{~mm}$ (Table 3).

Table 3: Antibacterial activity of $L$ hastata ethanol extract.

\begin{tabular}{|c|c|c|c|c|c|}
\hline \multirow{2}{*}{ Isolates } & \multicolumn{5}{|c|}{ Concentration $(\mathbf{m g} / \mathbf{m L}) /$ zone of inhibition (mm) } \\
\cline { 2 - 6 } & $\mathbf{2 5}$ & $\mathbf{5 0}$ & $\mathbf{7 5}$ & $\mathbf{1 0 0}$ & Control \\
\hline Klebsiella pneumoniae & $8.14 \pm 0.11 \mathrm{a}$ & $9.45 \pm 0.17 \mathrm{a}$ & $12.67 \pm 0.31 \mathrm{~b}$ & $14.13 \pm 0.25 \mathrm{bc}$ & 17.67 \\
\hline Salmonella typhi & $9.11 \pm 0.15 \mathrm{a}$ & $11.76 \pm 0.21 \mathrm{a}$ & $13.21 \pm 0.18 \mathrm{~b}$ & $15.34 \pm 0.36 \mathrm{c}$ & 19.34 \\
\hline Shigella sp & $9.23 \pm 0.11 \mathrm{a}$ & $12.15 \pm 0.20 \mathrm{~b}$ & $14.62 \pm 0.19 \mathrm{bc}$ & $16.31 \pm 0.33 \mathrm{c}$ & 19.34 \\
\hline Staphylococcus aureus & $10.17 \pm 0.34 \mathrm{a}$ & $13.17 \pm 0.22 \mathrm{~b}$ & $14.82 \pm 0.41 \mathrm{~b}$ & $17.41 \pm 0.22 \mathrm{c}$ & 20.67 \\
\hline Escherichia coli & $9.17 \pm 0.10 \mathrm{a}$ & $12.01 \pm 0.11 \mathrm{~b}$ & $14.22 \pm 0.23 \mathrm{~b}$ & $16.97 \pm 0.31 \mathrm{c}$ & 18.34 \\
\hline Proteus mirabilis & $9.14 \pm 0.17 \mathrm{a}$ & $10.55 \pm 0.20 \mathrm{a}$ & $13.13 \pm 0.25 \mathrm{~b}$ & $13.89 \pm 0.21 \mathrm{~b}$ & 19.67 \\
\hline
\end{tabular}

Key: Values having different superscript on the same row are considered significantly different at $p<0.05$. 


\section{MIC and MBC of aqueous and ethanol extracts}

Minimum inhibitory concentration of aqueous and ethanol extract of $L$ hastata is represented in table below Table 4 . The result showed dilutions of various concentrations of aqueous and ethanol extracts of the plant can inhibit the growth and kill the isolates. Lower MIC $(3.125 \mathrm{mg} / \mathrm{mL})$ was shown by ethanol extract than aqueous extract. MBC of the extracts ranges between $12.5-50 \mathrm{mg} /$ $\mathrm{mL}$ (Table 4).

Table 4: Minimum inhibitory concentration (MIC) and MBC of the extracts.

\begin{tabular}{|c|c|c|c|c|}
\hline \multirow{2}{*}{ Isolates } & \multicolumn{2}{|c|}{ Aqueous extract } & \multicolumn{2}{c|}{ Ethanol extract } \\
\cline { 2 - 5 } & MIC $(\mathbf{m g} / \mathbf{m L})$ & MBC (mg/mL) & MIC (mg/mL) & MBC (mg/mL) \\
\hline Klebsiella pneumoniae & 12.5 & 50 & 6.25 & 12.5 \\
\hline Salmonella typhi & 6.25 & 12.5 & 6.25 & 25 \\
\hline Shigella sp & 6.25 & 50 & 6.25 & 12.5 \\
\hline Staphylococcus aureus & 6.25 & 50 & 3.125 & 12.5 \\
\hline Escherichia coli & 6.25 & 25 & 6.25 & 25 \\
\hline Proteus mirabilis & 12.5 & 50 & & \\
\hline
\end{tabular}

Key: NF = Not found

\section{Discussion}

In the present study, the preliminary phytochemical screening of the plant material (leaf of Leptadenia hastata) revealed the presence of alkaloid, saponin, phenol, flavonoid, glycoside, tannin, steroid and terpenoid Table 2. The presence of various phytochemicals in Leptadenia hastata leaf extracts has also been reported by many researchers. The result of phytochemical screening of this study was in conformity with that of Bello et al. [9] conducted on phytochemical constituent of Leptadenia hastata. The results indicate the presence of phenolic glycosides, tannins, flavonoids, alkaloids and saponins.

These active phytochemicals are known for their medicinal activity as well as physiological actions; as such they confer the therapeutic potentials of all medicinal plants. Alkaloids, saponins, and tannins have been reported to inhibit bacterial growth and protective to plants against fungal infections [19]. Alkaloids comprising a large group of nitrogenous compounds are widely used as cancer chemotherapeutic agents, anaesthetics and Central Nervous Stimulants [20]. Alkaloids are known to play some metabolic roles and control development in living system. Anthraquinones were reported to be used as a laxative [21]. Flavonoids are also present in the extracts as a potent water-soluble antioxidant and free radical scavenger, which prevent oxidative cell damage and also have strong anticancer activity. Flavonoids were reported to suppress tumour growth and prevent blood clots [22]. Thus, the medicinal uses reported of Leptadenia hastata in managing constipation, its antimicrobial and antimalarial uses may be attributed to the presence of these phytochemical constituents.

The results of antibacterial activity of Leptadenia hastata leaf extracts in this study indicated that different extracts of Leptadenia hastata leaf have antibacterial activity with variable degree of sensitivity against isolates. The antibacterial activity of Leptadenia hastata leaf extracts could be attributed to the chemical properties of Leptadenia hastata leaf as mentioned above. According to the present study, the antibacterial activity of the extracts of Leptadenia hastata leaf showed that the ethanol extract demonstrated higher activity with average zone of inhibition of $12.56 \mathrm{~mm}$ while aqueous extract has average zone of inhibition of $11.22 \mathrm{~mm}$. The higher activity of ethanol extract may be due to better solubility of bioactive components in ethanol than in water. The result of this study was in conformity with that of Umaru, et al. [23] who studied the antibacterial activities of extract of Leptadenia hastata against Escherichia coli, Salmonella typhi, Staphylococcus aureus and Klebsiella pneumonia, and reported that of Leptadenia hastata were active against these bacteria with increase in concentration. The activity of this plant Leptadenia hastata was may be as a result of the presence of alkaloids, saponins, phenolic glycosides, tannins, flavonoids, proanthocyanidins and triterpenes [12]. This made him to conclude that the antibacterial activities observed can be due to the presence of these components obtained from the plant extracts. In agreement with the results of the present study, Raghavamma et al. [24] also reported the antibacterial activities of Leptadenia hastata.

The result of the present study showed dilutions of various concentrations of aqueous and ethanol extracts of the plant can inhibit the growth and kill the isolates with lower MIC and MBC in ethanol extract due to higher activity. According to the study, Gram positive bacterium (S. aureus) is the most sensitive organism in this study when compared to Gram negative ones. This implies that the extracts act by disrupting the synthesis of bacterial cell wall.

\section{Conclusion}

The Phytochemical screening of the $\mathrm{L}$. hastata revealed the present of alkaloid, tannin, saponin, and cardiac glycoside, flavonoid, terpenoid, phenols anthraquinones and steroid. The antibacterial activity of the leaf extract showed that the plant part extracts demonstrated antimicrobial effect against the tested isolates. Higher antibacterial activity was recorded in ethanol extract when compared to aqueous extract. Findings from this work support the use of extracts from L. hastata as medicinal plant.

\section{Acknowledgment}

None. 


\section{Conflict of Interest}

No conflict of interest.

\section{References}

1. Dubey N, Kumar R, Tripathi P (2004) Global promotion of herbal medicines: India's opportunity. Current Science Association 86(1): 3741.

2. Dias DA, Urban S, Roessner U (2012) A historical overview of natural products in drug discovery. Metabolites 2(2): 303-306.

3. Brahmachari G (2011) Natural products in drug discovery: impacts and opportunities an assessment. Bioactive Natural Products, pp. 1-199.

4. Kumara SM, Sudipta KM, Lokesh P, Neeki A, Rashmi W, et al. (2012) Phytochemical screening and in vitro antimicrobial activity of Bougainvillea spectabilis flower extracts. Int J Phytomed 4(3): 375-379.

5. Aquino R, Peluso G, De Tommasi N, De Simone F, Pizza C (1996) New polyoxypregnane ester derivatives from Leptadenia hastata. J Nat Prod 59(6): 555-564.

6. Ibrahim HA, Ali GY, Halliru SN, Usaini S, Abdullahi II (2012) Ethnobotanical survey of the wild edible food plants consumption among local communities in Kano State, North-Western, Nigeria. International Journal of Science and Technology 2(10): 713-717.

7. Dambatta S, Aliyu BS (2011) A survey of major ethnomedicinal plants of Kano North Nigeria, their knowledge and uses by traditional healers. Bayero Journal of Pure and Applied Sciences 4(2): 28-34.

8. Sasikala RP, Sangeetha K, Meena KS (2017) Comparative antibacterial and antifungal activities of benzene extract of three medicinal plants. Innovare J Life Sci 5(3): 3-5.

9. Bello A, Aliero AA, Saidu Y, Muhammad S (2011) Phytochemical Screening, Polyphenolic Content and Alpha-Glucosidase Inhibitory Potential of Leptadenia hastata (Pers.) Decne. Nigerian Journal of Basic and Applied Science 19(2): 181-186.

10. Aliero AA, Wara SH (2009) Validating the medicinal potential of Leptadenia hastata. Afr J Pharm Pharmacol 3: 335-338.

11. Patrick Y Hoekou, Tchadjobo Tchacondo, Koffi A Gbogbo, et al. (2015) Antibacterial activities of three latex plants of Asclepiadaceae family. Int J Curr Microbiol App Sci 4(5): 882-891.

12. Thomas SD (2012) Leptadenia hastata: A Review of its Traditional uses and its Pharmacological Activity. Med chem 2: 148-150.
13. Chessbrough M (2006) District laboratory practice in tropical countries $\left(2^{\text {nd }}\right.$ edn.) part two, Cambridge university press. Examination of pus, ulcer material and skin specimens. London, UK, pp. 80-85.

14. Holt JG, Krieg NR, Senath PHA, Staley JT, Williams ST (1994) Bergey's Manual of Determinative Bacteriology ( $9^{\text {th }}$ edn.). In: Baltimore Md Williams and Wilkins (Eds.), London, Uk.

15. Ali M, Yahaya A, Zage AU, Yusuf Z (2017) In-vitro Antibacterial Activity and Phytochemical Screening of Psidium guajava on Some Enteric Bacterial Isolates of Public Health Importance. Journal of Advances in Medical and Pharmaceutical Sciences 12(3): 1-7.

16. Sofowora A (1993) Medicinal plants and traditional medicine in Africa. ( $2^{\text {nd }}$ Edn.) Spectrum books ltd, pp. 26-100.

17. Trease GE, Evans WC (1989) Pharmacognosy (13 $3^{\text {th }}$ edn.). ELBS Oxford University Press, London, UK, pp. 245-263.

18. Ahmed I, Beg AZ (2001) Antimicrobial and phytochemical studies on 45 Indian Medicinal plants against multi-drug resistance human pathogens. J Ethnopharmacol 74(2): 113-123.

19. Doughari JH (2012) Phytochemicals: Extraction Methods, Basic Structures and Mode of Action as Potential Chemotherapeutic Agents. Phytochemicals - A Global Perspective of Their Role in Nutrition and Health, Nigeria, pp. 1-34.

20. Madziga HA, Sanni S, Sandabe UK (2010) Phytochemical and Elemental Analysis of Acalypha wilkesiana Leaf. Journal of American Science 6(11): 510-514.

21. Salah N, Miler NJ, Pagange G, Tijburg L, Bolwell GP, et al. (1995) Polyphenolic flavonoids as scavenger of aqueous phase radicals as chain breaking antioxidant. Arch Biochem Biophys 322(2): 339-346.

22. Rio DA, Obdululio BG, Casfillo J, Marin FG, Ortuno A (1997) Uses and properties of citrus flavonoids. J Agric Food Chem 45(12): 4505-4515.

23. Umaru IJ, Badruddin FA, Assim ZB, Umaru HA (2018) Antibacterial and cytotoxicity action of chloroform crude extract of Leptadenia hastata(pers) Decnee. Clin Med Biochemistry 4(1): 139.

24. Raghavamma STV, Rama Rao N, Sambasiva Rao, KRS, Devela Rao G (2013) Screening the leaf extract of Pergularia daemia (Forssk.) chiov for its antioxidant property and potential antimicrobial activities on medicinally important pathogens. International Journal of Phytopharmacology 4(3): 217-222. 